\title{
Pengembangan Kurikulum Bahasa Inggris Berbasis Teknologi Informasi dan Komunikasi (TIK) SD Tulangampiang, Denpasar, Bali dan Implemntasinya
}

\author{
Ambari Sutardi \\ Peneliti pada Pusat Kurikulum, Balitbang-Kemendiknas
}

\begin{abstract}
Abstrak: Tujuan penelitian ini yaitu untuk memperoleh informasi tentang pengembangan kurikulum bahasa Inggris berbasis teknologi, informasi, dan komunikasi (TIK) sekolah dasar (SD) Tulangampiang, Denpasar-Bali dan pelaksanaannya di kelas. Data dikumpulkan dengan cara studi dokumen, kuesioner, wawancara, dan pengamatan. Hasil penelitian menunjukkan bahwa guru bahasa Inggris mengembangkan kurikulum sesuai dengan panduan dari Badan Standar Nasional Pendidikan (BSNP), bahan ajar dikembangkan dari lingkungan peserta didik yang disusun dengan berbagai kegiatan pembelajaran.
\end{abstract}

Kata kunci: pengembangan kurikulum Bahasa Inggris dan teknologi informasi dan komunikasi

\begin{abstract}
The objective of this study is to get some information concerning English curriculum development based on ICT in Tulangampiang Primary School, Denpasar-Bali and its implementation in the classroom. The data was collected by analyzing documents, distributing questionnaire, interview students and teacher, and observing the grade $V$. The result shows that the teachers had already developed English curriculum in line with a manual provided by BSNP, the learning-teaching materials were taken from the learners surroundings, and be arranged with a variety of learning activities.
\end{abstract}

Key words: curriculum development for English language and technology communication information

\section{Pendahuluan}

Kebijakan pemerintah mengizinkan sekolah dasar (SD) untuk mengajarkan Bahasa Inggris mulai dari kelas empat (Depdikbud, 1994) merupakan suatu langkah baik karena memberi kesempatan kepada peserta didik untuk belajar bahasa tersebut lebih dini dibanding kebijakan sebelumnya yang memberi kesempatan mulai sejak semester satu kelas satu SMP. Pada waktu yang bersamaan ditentukan pula bahwa mata pelajaran bahasa Inggris di SD merupakan mata pelajaran kelompok muatan lokal yang statusnya sebagai mata pelajaran pilihan, sehingga materinya pun ditentukan oleh sekolah masing-masing. Sementara itu, pada jenjang berikutnya Bahasa Inggris sebagai mata pelajaran wajib sampai saat ini. Oleh karena statusnya sebagai mata pelajaran pilihan, sehingga pada tingkat pelaksanaannya berbedabeda. Ada sekolah yang mulai mengajarkannya di kelas empat, ada pula yang mulai mengajarkannya dari kelas satu SD dan bahkan ada yang belum mengajarkannya hingga tahun 2009.

Fenomena ini terjadi kemungkinan karena adanya berbagai faktor yang dapat berpengaruh terhadap pelaksanaan program tersebut. Misalnya: a) status mata pelajaran sampai saat ini masih sebagai mata pelajaran pilihan; b) jumlah guru yang belum mencukupi karena tidak ada pengangkatan guru Bahasa Inggris SD secara resmi dari pemerintah; c) guru Bahasa Inggris yang memiliki kualifikasi mengajar di SD belum memadai karena belum banyak perguruan tinggi yang memberi mata kuliah "English for Young Learners"; dan d) tidak ada sumber mengajar yang dapat dijadikan rujukan yang pasti bagi guru.

Akar permasalahannya antara lain diasumsikan ketika kebijakan digulirkan, Pemerintah tidak serta merta menyediakan kurikulum dan pedoman pelaksanaannya, sehingga guru dan penulis buku Bahasa Inggris tidak memiliki rujukan yang pasti dalam menentukan bahan ajar yang akan ditulis dan disampaikan kepada peserta didik di kelas. Hal ini berakibat pada: a) bahan yang dihasilkan oleh penulis buku dan digunakan di SD sangat bervariatif; dan b) sebagian peserta didik merasa mengalami kesulitan dalam belajar (Ambari Sutardi, Media Jarlit, Nomor 5, Maret, 2005). Permasalahan ini perlu diatasi dengan baik oleh instansi yang berwenang melalui berbagai cara agar guru dan peserta didik masing-masing sebagai perancang 
dan penerima bahan memperoleh berbagai kemudahan.

Pemerintah telah memperhatikan penetapan program Bahasa Inggris di SD yang direalisasikan dalam bentuk peraturan Menteri Pendidikan Nasional melalui Permendiknas Nomor 22 Tentang Standar Isi (SI) 2006 yang lampirannya memuat standar kompetensi (SK) dan kompetensi dasar (KD) minimal bahasa Inggris di SD. Di samping itu, Permendiknas Nomor 24 Tentang Pelaksanaan Standar Isi (SI) dan Standar Kompetensi Lulusan (SKL) secara eksplisit menugaskan Badan Penelitian dan Pengembangan (Balitbang) Kementerian Pendidikan Nasional untuk mengembangkan dan mengujicobakan modelmodel kurikulum dan pembelajaran. Namun, pada tahap pelaksanaannya pengembangan dan pelaksanaan ujicoba model-model tersebut diserahkan kepada Pusat Kurikulum (Puskur). Berdasarkan tugas dan pertimbangan tersebut, Puskur mengadakan kerjasama dengan berbagai sekolah tertentu pada jenjang pendidikan dasar dan menengah di berbagai daerah.

Salah satu sekolah yang bekerjasama dengan Puskur selama tahun ajaran 2009 adalah SD Tulangampiang Denpasar, Bali dan juga melibatkan pihak Dinas Pendidikan Provinsi Bali. Atas dasar kesepahaman bersama antara Pusat Kurikulum, Dinas Pendidikan Provinsi Bali dan SD tersebut. Hasilnya berupa contoh pengembangan kurikulum Bahasa Inggris SD berbasis Teknologi Informasi dan Komunikasi (TIK) semester dua kelas $\checkmark$ dengan judul Public Places untuk satu kali pertemuan ( 2 X 35 menit). Pengembangan kurikulum Nahasa Inggris tersebut merujuk pada SK dan KD minimal Bahasa Inggris SD yang tertuang dalam Lampiran SI 2006. Hasil pengembangan berupa bahan ajar yang dikemas dalam bentuk soft-file dan rencananya dimasukkan ke website oleh Puskur. Diharapkan bahan tersebut dapat diakses oleh masyarakat umum.

Beberapa rumusan permasalahan yaitu: 1) Apakah Guru bahasa Inggris di SD Tulangampiang dapat menyusun Silabus dan RPP sesuai dengan Panduan Badan Standar Nasional Pendidikan (BSNP, 2006); 2) Apakah bahan ajar (topik, gambar/foto, kosakata, pelafalan/ucapan, kalimat, paragraph, teks dan jenis kegiatan) yang dikembangkan dengan menggunakan TIK sederhana dan mudah bagi peserta didik?, 3) Apakah guru mendominasi peran selama pelaksanaan pembelajaran berlangsung?, 4) Apakah guru memberi perhatian kepada peserta didik? 5) Bagaimana pendapat guru tentang bahan yang disusun dan disajikan?, 6) Bagaimana peran peserta didik selama kegiatan pembelajaran? 7) Apakah peserta didik memperhatikan bahan ajar yang ditayangkan di layar?, 8) Apa pendapat peserta didik tentang materi yang disajikan?, 9) Bagaimana perasaan peserta didik?

Penelitian ini bertujuan untuk memperoleh informasi tentang pengembangan kurikulum bahasa Inggris berbasis TIK SD Tulangampiang, Denpasar Bali dan pelaksanaannya di kelas. Lebih lanjut, informasi pengembangan kurikulum meliputi silabus, RPP, bahan ajar (topik, gambar/ foto, kosakata, pelafalan, kalimat, paragraph, teks, dan jenis kegiatan)

\section{Kajian Literatur}

Bahan rujukan untuk pengembangan kurikulum bahasa Inggris SD meliputi Surat Keputusan (SK) dan Kompetensai Dasar (KD) minimal yang tertuang di dalam Lampiran Permendiknas Nomor 22, Tahun 2006. Contoh SK dan KD bahasa Inggris kelas V SD semester 2 sebagai berikut.

Surat Keputusan dan Kompetensi Dasar di atas masih bersifat umum dan akan sulit bagi guru bila langsung diaplikasikan di kelas. Oleh karena itu, guru harus menjabarkan dalam bentuk yang lebih spesifik yaitu silabus dan Rencana Pelaksanaan Pembelajaran (RPP) yang merupakan bagian dari kurikulum sekolah.

Silabus harus memuat "standar kompetensi, kompetensi dasar, materi pokok/ pembelajaran, kegiatan pembelajaran, indikator, penilaian, alokasi waktu, dan sumber/bahan/alat belajar" (Panduan Penyusunan Kurikulum Tingkat Satuan Pendidikan jenjang pendidikan dasar dan menengah, BSNP:2006). Adapun RPP memuat sekurang-kurangnya "tujuan pembelajaran, materi ajar, metode pengajaran, sumber belajar, dan penilaian hasil belajar". (Peraturan Pemerintah-PP Nomor 19, Tahun 2005, Bab IV tentang Standar Proses, pasal 20). Tentang RPP ini diuraikan lebih lanjut di dalam Lampiran Permendiknas Nomor 41, Tahun 2007 Tentang Standar Proses, bagian II: Perencaan Proses 


\begin{tabular}{|c|c|}
\hline Standar Kompetensi (SK) & Kompetensi Dasar (KD) \\
\hline $\begin{array}{l}\text { Mendengarkan } \\
\text { Memahami instruksi } \\
\text { sangat sederhana } \\
\text { dengan tindakan dalam } \\
\text { konteks sekolah }\end{array}$ & $\begin{array}{l}\text { 1.1 Merespon instruksi sangat sederhana dengan tindakan secara berterima } \\
\text { dalam konteks sekolah } \\
\text { 1.2 Merespon instruksi sangat sederhana secara verbal }\end{array}$ \\
\hline $\begin{array}{l}\text { Berbicara } \\
\text { 2. Mengungkapkan } \\
\text { instruksi dan informasi } \\
\text { sangat sederhana } \\
\text { dalam konteks sekolah }\end{array}$ & $\begin{array}{l}\text { 2.1 Bercakap-cakap untuk menyertai tindakan secara berterima yang } \\
\text { melibatkan tindak tutur: memberi contoh melakukan sesuatu, memberi } \\
\text { aba-aba, dan memberi petunjuk } \\
\text { 2.2 Bercakap-cakap untuk meminta/memberi jasa/barang secara berterima } \\
\text { yang melibatkan tindak tutur: meminta bantuan, memberi bantuan, } \\
\text { meminta barang, dan memberi barang } \\
\text { 2.3 Bercakap-cakap untuk meminta/memberi informasi secara berterima } \\
\text { yang melibatkan tindak tutur: memberi informasi, memberi pendapat, } \\
\text { dan meminta kejelasan } \\
\text { 2.4 Mengungkapkan kesantunan secara berterima yang melibatkan } \\
\text { ungkapan: do you mind ... dan Shall we ... }\end{array}$ \\
\hline $\begin{array}{l}\text { Membaca } \\
\text { 3. Memahami tulisan } \\
\text { bahasa Inggris sangat } \\
\text { sederhana dalam } \\
\text { konteks sekolah }\end{array}$ & $\begin{array}{l}\text { 3.1 Membaca nyaring dengan ucapan, tekanan, dan intonasi secara tepat } \\
\text { dan berterima yang melibatkan: kata, frasa, kalimat sangat sederhana, } \\
\text { dan teks sangat sederhana } \\
\text { 3.2 Memahami kalimat, pesan tertulis dan teks deskriptif bergambar sangat } \\
\text { sederhana secara tepat dan berterima }\end{array}$ \\
\hline $\begin{array}{l}\text { Menulis } \\
\text { 4. Mengeja dan menyalin } \\
\text { kalimat sangat } \\
\text { sederhana dalam } \\
\text { konteks sekolah }\end{array}$ & $\begin{array}{l}\text { 4.1 Mengeja kalimat sangat sederhana secara tepat dan berterima } \\
\text { 4.2 Menyalin dan menulis kalimat sangat sederhana secara tepat dan } \\
\text { berterima dengan tanda baca yang tepat seperti: ucapan selamat, } \\
\text { ucapan terima kasih, dan ucapan simpati }\end{array}$ \\
\hline
\end{tabular}

(Lampiran Permendiknas Nomor 22, Tahun 2006, tentang SI untuk satuan pendidikan dasar dan menengah, bagian SK dan KD bahasa Inggris kelas V SD semester 2 Nomor 36 )

Pembelajaran yaitu memuat "identitas mata pelajaran, standar kompetensi, kompetensi dasar, indikator pencapaian kompetensi, tujuan pembelajaran, materi ajar, alokasi waktu, metode pembelajaran, kegiatan pembelajaran, penilaian hasil belajar, sumber belajar".

Dari uraian di atas RPP memuat uraian materi yang lebih rinci dari pada di dalam silabus dan kerinciannya ini perlu diikuti dengan pertimbangan tentang penyesuaian terhadap kebutuhan dalam kehidupan peserta didik sehari-hari, apalagi mereka masih pada tahap kelompok belajar pemula. Topik-topik yang dipilih harus disusun atas dasar prinsip umum: mulai dari yang konkrit ke yang abstrak, dari yang paling sering dijumpai mereka ke yang paling jarang.

Prinsip tersebut ditegaskan oleh Harmer (1991) bahwa "to teach more concreate words at lower levels and gradually become more abstract. The words which are most commonly used are the ones we should teach first." Pada tahap pemula penekanan penyampaian materi lebih berfokus pada penambahan perbendaharaan kosakata, sementara tata bahasa agak dibelakangkan.

Hal senada diungkapkan juga oleh Willis, J. (1999) mengatakan bahwa "for the beginners words and phrases before grammar. It is nearly always lack of vocabulary that prevents learners from understanding". Artinya, untuk konteks Indonesia, apalagi bahasa Inggris bukan mata pelajaran wajib, "grammar" atau tata bahasa sebaiknya jangan menjadi prioritas bahan ajar untuk disampaikan kepada peserta didik agar mereka tidak takut untuk berbicara dalam bahasa target mereka.

Woods (1995) nampaknya memiliki data yang lebih konkrit dan ada kaitannya dengan mengajarkan tata bahasa. Beliau mengatakan bahwa" in Britain it was shown that L1 pupils who had been taught grammar were no better or worse in speaking and in writing than those who had not had grammar classes...Thus there was no need for a focus on grammar". 
Meskipun demikian, beban peserta didik untuk mempelajari kosakata baru jangan terlalu berat. Artinya, jumlah kosakata baru yang harus dikuasai dalam satu kali pertemuan harus dibatasi dan disesuaikan dengan kemampuan mereka, bahkan Finocchiaro dan Brumfit (1983) menyarankan "at elementary school levels only about three to five new words should be presented for active use in one lesson".

Perpaduan antara kosakata menjadi frasa dan kalimat baik lisan dan atau tertulis merupakan ungkapan-ungkapan yang harus dikaitkan dengan konteks yang sering digunakan oleh peserta didik dalam kehidupan mereka sehari-hari agar belajar di sekolah menjadi bermanfaat. Nunan, D. (1989) sependapat tentang hal ini dan menegaskan "the material is related to language use outside the classroom", begitu pula Cameron, L. (2001) yang mengatakan "the materials should be related to real needs of learners, such as reading bus timetables or buying cinema tickets." Oleh karena itu, materi pembelajaran jangan terlalu asing bagi dan disesuaikan dengan kehidupan mereka sehari-hari.

Di samping itu, bahan yang disajikan sebaiknya menarik bagi peserta didik. Sifat menarik dapat diciptakan dari berbagai sisi tampilan. Misalnya, menggunakan berbagai foto yang berwarna, cerita yang sederhana dan mudah difahami serta tampilan permainan yang menuntut peserta didik aktif berdialog atau melaksanakan tugas lainnya dengan teman mereka yang menimbulkan rasa senang.

Penny Ur (1996) memperhatikan hal ini dengan menegaskan "pictures, stories and games are very important sources of interest for children in the classroom. The first being obviously mainly a visual stimulus; the second both visual and aural; and the third using both visual and aural channels as well as activating language production and sometimes physical movement."

Permainan atau "games" dimaksud di atas tentunya permainan yang merangsang peserta didik untuk lebih membentuk keterampilan dasar dalam berbahasa target mereka."Learning Games are a great way to build the foundation skills". (http:/ /www. Learning gamesforkids.com/) karena "melalui kegiatan bermain, daya pikir anak terangsang untuk mendayagunakan aspek emosional, sosial serta fisiknya." (SHVOONG, 2007). Terciptanya atmosfir di kelas yang sesuai dengan harapan tergantung kepada keinginan dan kreatifitas guru sebagai pengelola kegiatan pembelajaran.

Agar permainan menimbulkan rangsangan dan rasa senang terhadap peserta didik, tentunya perancang bahan dituntut cermat dalam menyesuaikan bahan dengan tingkat kemampuan mereka. Sebaiknya, permainan juga menimbulkan keseimbangan antara kegiatan untuk bermain dan untuk belajar sehingga alat/bahan tersebut menjadi efektif. Karena itu perancang sebaiknya memahami benar tingkat kemampuan peserta didik yang akan menjadi sasaran dari bahan ajar yang dirancangnya -"The issue of regulating game content is vital as educational game are created to be effective learning tools. Thus the game developer must have a comprehensive understanding of its young audience and their particular social and educational needs. At the same time, the game developer must balance between entertainment and accordance with the education syllabus" (WIKIPEDIA, 2010a).

Praktik berbahasa secara maksimal dapat dikategorikan pembelajaran yang aktif atau "active learning" dan ini baik bagi peserta didik secara kognitif maupun fisik karena mereka dapat berkonsentrasi ke materi guna memahami bahan ajar yang mereka terima dan mempraktikkannya dengan teman mereka baik secara lisan maupun tertulis. "Active learning refers to learning that occurs through instructional strategies that engage students intellectually and physically as they pursue given classroom assignments"(California http:// pubs. cde.ca.gov/tcsii/ap/glossary.aspx). Hubungannya dengan pembelajaran aktif atau "active learning" Pemerintah bahkan mengeluarkan kebijakan yang menegaskan "Proses pembelajaran pada satuan pendidikan diselenggarakan secara interaktif, inspiratif, menyenangkan, menantang, memotivasi peserta didik untuk berpartisipasi aktif, serta memberikan ruang yang cukup bagi prakarsa, kreativitas, dan kemandirian sesuai dengan bakat, minat, dan perkembangan fisik serta psikologis peserta didik". (Peraturan Pemerintah Nomor 19, Tahun 2005).

Perlunya pelaksanaan pembelajaran secara aktif ini ditegaskan lagi oleh pemerintah melalui 
Instruksi Presiden Republik Indonesia Nomor 1 Tahun 2010 Tentang Percepatan Pelaksanaan Prioritas Pembangunan Nasional Tahun 2010, khususnya mengenai Prioritas 2, tentang Program Penguatan metodologi dan kurikulum. Pembelajaran aktif terlaksana bila peran guru di kelas tidak dominan atau cenderung sebagai fasilitator saja. Hal senada diungkapkan oleh Breen dan Candlin (1980) dengan mengatakan "teachers should act as fasilitator and model".

Kebijakan Pemerintah di atas, sejalan dengan pendapat yang diungkapkan oleh para ahli sebelumnya, antara lain Richards dan Rodgers (1994). Mereka menegaskan "activities involving real communication promote learning". Kegiatan komunikasi lisan antar peserta didik dalam bahasa target mereka juga penting karena mereka akan memanfaatkan berbagai simpanan/ pengetahuan bahasa-"In communication, students can use all they possess of the language"(Rivers 1987). Agar komunikasi berbahasa lisan terjadi, guru yang merancang pembelajaran sebaiknya mengarahkan peserta didik berpasangan dan atau berkelompok karena dengan cara ini memungkinkan mereka melakukan praktik berbahasa lisan dengan bahasa yang dipelajarinya.

Hyde (1993) bahkan menegaskan "in pairs learners can develop productive skills". Ungkapan yang serupa juga ditegaskan oleh Holliday (1994) dengan mengatakan "activities in groups enable students to communicate", begitu pula oleh Harmer (1991) dengan menyatakan "Group work can be used for oral, reading, listening and writing tasks".

Ada kiat-kiat agar guru yang mengajar di kelas tidak dominan, namun bahan ajar yang disampikan menarik dan peserta didik aktif mengembangkan empat keterampilan berbahasa, antara lain perancang bahan menggunakan media yang sesuai dengan tujuan pembelajaran dan topik yang dipilih. "Media yang tepat sesuai dengan tujuan akan mampu meningkatkan pengalaman belajar yang mampu mempertinggi hasil belajar" (Jurusan Kurikulum dan Teknologi Pendidikan, FIP-UPI, 2007).

TIK atau dalam bahasa Inggris dikenal dengan istilah ICT merupakan bagian dari media yang dapat dimanfaatkan oleh guru untuk merancang bahan pembelajaran. Dengan TIK, perancang bahan ajar akan memperoleh kemudahan dalam merekayasa tampilan bahan yang lebih menarik bagi peserta didik. Tampilan hasil rekayasa yang menarik dan sesuai dengan tujuan pembelajaran perlu disosialisasikan melalui website agar mudah diakses oleh orang lain dalam waktu singkat dengan jumlah pengguna yang relatif banyak, namun tidak memerlukan biaya yang jumlahnya relatif besar, dan ini akan sangat efisien dan efektif. -"ICT can be employed to give users quick access to ideas and experiences from a wide range of people" (Wikipedia, 2010b). Dengan kata lain, TIK yang merupakan bagian dari teknologi dapat dimanfaatkan untuk mengembangkan kurikulum yang akan disampaikan kepada peserta didik sehingga mereka akan mengalami kemudahan belajar - "Educational technology (also called learning technology) is the study and ethical practice of facilitating learning, educational technology includes other systems used in the process of developing human capability" (Wikipedia, 2010c).

\section{Metode Penelitian Populasi dan Sampel}

Populasi studi ini adalah semua SD yang ada di Denpasar sedangkan sampelnya adalah SD Tulangampiang, Denpasar, Bali yang dipilih dengan menggunakan teknik "purposive random sampling". Yang menjadi responden yaitu peserta didik kelas 5 sebanyak 34 orang. Pemilihan sekolah didasarkan atas informasi dari Direktorat Pembinaan Taman kanak-Kanak dan Sekolah Dasar, Direktorat Jenderal Manajemen Pendidikan Dasar dan Menengah, Dinas Pendidikan Provinsi Bali di Denpasar serta Pusat Kurikulum. Pelaksanaan ujicoba penggunaan hasil pengembangan kurikulum dengan memanfaatkan TIK di kelas $\mathrm{V}$ dan tema tentang tempat umum atau "Public Places" atas keputusan bersama antara Pusat Kurikulum, Dinas Pendidikan Provinsi Bali dan pihak sekolah.

\section{Instrumen}

Instrumen yang digunakan dalam penelitian ini adalah hasil pengembangan kurikulum berbasis TIK dalam bentuk soft-file (CD), alat pengamatan, pedoman wawancara bagi guru dan peserta didik serta kuesioner bagi peserta didik. 


\section{Teknik Pengumpulan Data}

Penelitian ini diselenggarakan pada bulan Agustus 2009 ketika Pusat Kurikulum sebagai salah satu pendukung pengembangan kurikulum Bahasa Inggris SD berbasis TIK melaksanakan ujicoba hasil pengembangannya di kelas $V$ SD tersebut. Data dikumpulkan melalui studi dokumen, pengamatan, wawancara dan kuesioner. Studi dokumen mencakup kegiatan menganalisis SK dan KD dari SI 2006, silabus, RPP dan bahan ajar bahasa Inggris kelas $V$; pengamatan dilaksanakan selama tujuh puluh menit ketika kegiatan pembelajaran sedang berlangsung; wawancara dengan guru yang mengajar dan peserta didik

\section{Silabus}

Nama Sekolah

Mata Pelajaran

Kelas

Semester

Tema

Standar Kompetensi

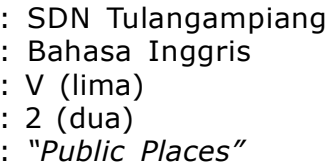

: 1) Mendengarkan: Memahami instruksi sangat sederhana dengan tindakan dalam konteks sekolah; 2) Berbicara: Mengungkapkan instruksi dan informasi sangat sederhana dalam konteks sekolah; 3) Membaca: Memahami tulisan bahasa Inggris sangat sederhana dalam konteks sekolah, dan 4) Menulis: Mengeja dan menyalin kalimat sangat sederhana dalam konteks sekolah

\begin{tabular}{|c|c|c|c|c|c|c|}
\hline Kompetensi Dasar & $\begin{array}{c}\text { Materi Pokok } \\
\text { dan Uraian } \\
\text { Materi }\end{array}$ & $\begin{array}{c}\text { Kegiatan } \\
\text { Pembe- } \\
\text { lajaran }\end{array}$ & Indikator & $\begin{array}{l}\text { Peni- } \\
\text { Iaian }\end{array}$ & $\begin{array}{l}\text { Aloka } \\
\text { si } \\
\text { Wak } \\
\text { tu }\end{array}$ & $\begin{array}{c}\text { Sumber } \\
\text { Belajar }\end{array}$ \\
\hline $\begin{array}{l}\text { Public Places } \\
\text { 1.Mendengarkan } \\
\text { 1.1 Merspon instruksi sangat } \\
\text { sederhana dengan tindakan } \\
\text { 1.2. Merespon instruksi sangat } \\
\text { sederhana secara verbal } \\
\text { 2.Berbicara } \\
\text { 2.1 Bercakap-cakap untuk } \\
\text { menyertai tindakan secara } \\
\text { berterima yang melibatkan } \\
\text { tindak tutur: memberi contoh } \\
\text { melakukan sesuatu, dan } \\
\text { memberi petunjuk } \\
\text { 3. Membaca } \\
\text { 3.1 Membaca nyaring dengan } \\
\text { ucapan, tekanan, dan intonasi } \\
\text { secara tepat dan berterima } \\
\text { yang melibatkan: kata, frasa, } \\
\text { kalimat sangat sederhana, dan } \\
\text { teks sangat sederhana } \\
\text { 3.2 Memahami kalimat, pesan } \\
\text { tertulis dan teks deskriptif } \\
\text { bergambar sangat sederhana } \\
\text { secara tepat dan berterima } \\
\text { 4. Menulis } \\
\text { 4.2 Menyalin dan menulis } \\
\text { kalimat sangat sederhana } \\
\text { secara tepat dan berterima } \\
\text { dengan tanda baca yang tepat } \\
\text { seperti: ucapan selamat, } \\
\text { ucapan terima kasih, dan } \\
\text { ucapan simpati }\end{array}$ & $\begin{array}{l}\text { Kosakata yang } \\
\text { berkaitan } \\
\text { dengan public } \\
\text { places. } \\
\text { Gambit / } \\
\text { ungkapan } \\
\text { yang diguna- } \\
\text { kan untuk } \\
\text { menanyakan } \\
\text { dan merespon } \\
\text { pertanyaan } \\
\text { tentang } \\
\text { tempat- } \\
\text { tempat } \\
\text { umum. } \\
\text { Teks descriptif } \\
\text { yang } \\
\text { berkaitan } \\
\text { dengan } \\
\text { tempat- } \\
\text { tempat umum } \\
\text { Menanyakan } \\
\text { lokasi, dan } \\
\text { fungsi suatu } \\
\text { tempat } \\
\text { Menggunakan } \\
\text { preposisi on, } \\
\text { in, at, beside, } \\
\text { behind, in } \\
\text { front of dan } \\
\text { across }\end{array}$ & $\begin{array}{l}\text { Memberi } \\
\text { nama tem- } \\
\text { pat pada } \\
\text { gambar se- } \\
\text { suai dengan } \\
\text { fungsinya } \\
\text { yang disam- } \\
\text { paikan } \\
\text { secara lisan } \\
\text { Membuat } \\
\text { dialog ten- } \\
\text { tang tempat } \\
\text { umum yang } \\
\text { pernah di- } \\
\text { kunjungi dan } \\
\text { mendemontr } \\
\text { asikan di } \\
\text { depan kelas } \\
\text { Membaca } \\
\text { teks tentang } \\
\text { tempat } \\
\text { umum } \\
\text { secara } \\
\text { bergiliran } \\
\text { Menjawab } \\
\text { pertanyaan } \\
\text { sesuai } \\
\text { dengan isi } \\
\text { teks } \\
\text { Menulis } \\
\text { kalimat dan } \\
\text { paragrap }\end{array}$ & $\begin{array}{l}\text { Mengidenti } \\
\text { fikasi } \\
\text { tempat- } \\
\text { tempat } \\
\text { umum } \\
\text { sesuai } \\
\text { dengan } \\
\text { fungsinya } \\
\text { Berdialog } \\
\text { tentang } \\
\text { tempat } \\
\text { umum dan } \\
\text { fungsinya } \\
\text { Membaca } \\
\text { dengan } \\
\text { ucapan } \\
\text { yang benar } \\
\text { Mencari } \\
\text { informasi } \\
\text { tentang } \\
\text { tempat } \\
\text { umum } \\
\text { pada teks. } \\
\text { Menulis } \\
\text { paragraph } \\
\text { pendek } \\
\text { tentang } \\
\text { perpustaka } \\
\text { an }\end{array}$ & $\begin{array}{l}\text { Tes } \\
\text { lisan } \\
\text { dan } \\
\text { ter- } \\
\text { tulis }\end{array}$ & $\begin{array}{l}4 \times \\
\text { perte } \\
\text { muan }\end{array}$ & $\begin{array}{l}\text { Begin- } \\
\text { ners for } \\
\text { elementa } \\
\text { ry school } \\
\text { (pustaka } \\
\text { tarukan } \\
\text { agung) } \\
\text { Go with } \\
\text { English } 6 \\
\text { (yudis } \\
\text { tira) } \\
\text { VCD } \\
\text { kids } \\
\text { english }\end{array}$ \\
\hline
\end{tabular}

(Silabus Kelas V Semester 2, SD Tulangampiang, 2009) 
yang juga merangkap sebagai responden setelah kegiatan pembelajaran berlangsung; dan memberi kuestioner kepada peserta didik.

\section{Teknik Analisis Data}

Data yang diperoleh melalui studi dokumen, pengamatan, wawancara, dan kuesioner dipilah berdasarkan aspek-aspek yang ditentukan sebelumnya, kemudian diuraikan secara deskriptif.

\section{Hasil Penelitian dan Pembahasan}

Hasil penelitian menunjukkan bahwa guru-guru bahasa Inggris SD Tulangamping tersebut telah mengembangkan kurikukum Bahasa Inggris dalam bentuk silabus, RPP dan bahan ajar berbasis Teknologi Informasi dan Komunikasi berdasarkan SK dan KD dari SI 2006. Berikut adalah salahsatu contoh untuk masing-masing silabus dan RPP untuk kelas $\mathrm{V}$ semester 2 .

\section{Rencana Pelaksanaan Pembelajaran ( RPP )}

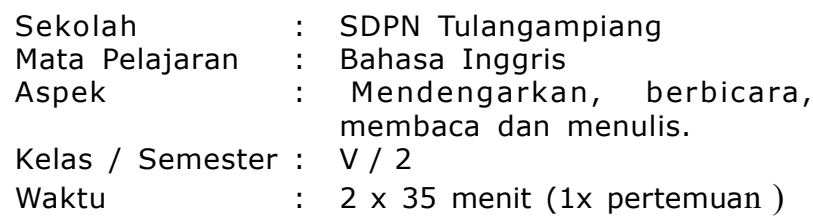

Standar Kompetensi, meliputi: 1) Mendengarkan: Memahami instruksi sangat sederhana dengan tindakan dalam konteks sekolah; 2) .Berbicara: Mengungkapkan instruksi dan informasi sangat sederhana dalam konteks sekolah, 3) Membaca:Memahami tulisan bahasa Inggris sangat sederhana dalam konteks sekolah; dan 4) Menulis: Menyalin kalimat sangat sederhana dalam konteks sekolah

\section{Kompetensi Dasar}

Mendengarkan, meliputi: 1) Merespon instruksi sangat sederhana dengan tindakan yaitu mendengarkan dialog dan instruksi yang di dengar baik dari bahan ajar yang direkam maupun dari guru yang mengajar secara langsung; dan 2) Merespon instruksi lisan sangat sederhana secara verbal melalui dialog singkat.

Berbicara, mencakup bercakap-cakap untuk meminta dan memberi petunjuk/informasi tentang tempat umum, seperti "Museum, Bank, Post Office dan dan melafalkan kata-kata yang dianggap sulit.
Membaca, meliputi: 1) Membaca nyaring teks/ cerita tentang "Bali Museum", "Art Center", "City Park", "Jagatnatha" yang menggunakan kata, frasa, kalimat sangat sederhana; 2) Memahami kata, kalimat, pesan tertulis dan teks deskriptif bergambar sangat sederhana dari topik-topik "Bali Museum", "Art Center", "City Park", "Jagatnatha".

Menulis, mencakup menulis kalimat sangat sederhana secara tepat seperti: You can read books in the library, Go straight in this way".

Indikator, meliputi: a) Merespon lawan bicara secara verbal dengan benar; b) Membaca bersuara empat teks tersebut di atas dengan benar; dan c) Menulis kata dan kalimat yang didiktekan

\section{Materi pokok, Tema: "Public Places"}

Topik-topik: "Post office, Art Centre, Zoo, Museum, City Park, Bus Station, Library, Hotel, Beach, Bank, Restaurant, Botanical Garden, Hospital, and Stadium".

Uraian materi: a) Kosakata yang berkaitan dengan topik-topik yang digunakan; dan b) Ungkapan yang digunakan untuk memberi dan meminta informasi yang berkaitan dengan topiktopik tertentu seperti: 1) What are there in the museum? 2) Where can I send a letter? Dan 3) I want to go to the bank, etc; b) Teks/Cerita pendek tentang "Bali Museum, Art Center, City Park, dan Jagatnatha".

\section{Kegiatan Pembelajaran}

Kegiatan awal, meliputi: a) Menyampaikan informasi tentang kegiatan pembelajaran yang harus diperhatikan dan diikuti oleh mereka; dan b) Mendengarkan dan menyebutkan nama-nama tempat umum seperti, Museum, Beach, City Park, dan sebagainya.

Kegiatan inti, meliputi: a) Menyimak instruksi, percakapan dan teks sederhana tentang "Bali Museum, Art Center, City Park, Jagatnatha" yang dibacakan; b) Membaca bersuara teks-teks yang disediakan; dan c) Menjawab pertanyaan berdasarkan teks, d) Mengadakan permainan berbahasa dengan memilih kalimat yang benar, memilih kata/frasa dengan fungsinya yang ada di sisi lain. 
Kegiatan penutup, mencakup: 1) Melafalkan katakata yang dianggap sulit, misalnya church, exhibition; dan 2) Melatih mendengarkan kalimat dan menuliskannya, misalnya We can read books in the library.

Metode Pembelajaran: a) Penyajian tayangan $\mathrm{CD}$; b) Tanya jawab; dan c) Praktik berbahasa lisan dan tertulis

Sumber Belajar, meliputi: a) Go with English 5; b) Beginners for elementary school; dan c) Bukubuku lain yang relevan

Penilaian: Tes lisan dan tertulis (RPP Kelas V, semester 2, SD Tulangampiang, 2009)

Berdasarkan contoh silabus dan RPP di atas, guru bahasa Inggris SD Tulangampiang telah memahami pola penyusunan silabus dan RPP berdasarkan Peraturan Pemerintah-PP Nomor 19, Tahun 2005, tentang Standar Nasional Pendidikan, pasal 20; Panduan Penyusunan Kurikulum Tingkat Satuan Pendidikan jenjang pendidikan dasar dan menengah, BSNP: 2006; dan Lampiran Permendiknas Nomor 41, Tahun 2007 Tentang Standar Proses, bagian II Perencaan Proses Pembelajaran.

Bahan ajar Bahasa Inggris yang dikembangkan berdasarkan kurikulum serta menggunakan TIK dilengkapi dengan suara, dikemas dalam bentuk soft-file dan dipraktikkan di kelas dengan menggunakan Laptop dan Infocus. Gambaran bahan ajar yang disusun dan pelaksanaannya di kelas sebagai berikut: Bahan ajar berjudul: "Model Pembelajaran Bahasa Inggris SD Tulangampiang Denpasar Bali Berbasis TIK". Bila kursor ditujukan ke judul, kemudian ditekan, maka akan terlihat daftar isi, terdiri atas tiga bagian yang tertulis dengan "pre-activities, core activities" dan "post activities". Sesi pertama, "Pre-activities" atau kegiatan awal terdiri dari dua sub-bagian, "Listen and Repeat!" dan "quiz" (permainan). Penyajian sesi "Listen and Repeat" dimulai dengan menampilkan satu per satu foto-foto berwarna mengenai "Public Places" atau tempat umum yang meliputi; Kantor Pos, Pusat Kesenian, Kebun Binatang, Musium, Taman Kota, Terminal Bis, Perpustakaan, Hotel, Pantai, Bank, Restoran, Taman, Rumah Sakit dan Stadion.

Segera setelah satu foto terlihat di layar, secara otomatis diikuti dengan penampilan namanya yang tertulis di bawahnya dalam Bahasa Inggris, seperti; "Post office, Art Centre, Zoo, Museum, City Park, Bus Station, Library, Hotel, Beach, Bank, Restaurant, Botanical Garden, Hospital, and Stadium." Nama dalam Bahasa Inggris kemudian diucapkan bersuara di dalam kegiatan pembelajaran dan peserta didik ditugaskan untuk mengikutinya. Foto-foto yang merupakan bahan ajar diambil dari lingkungan peserta didik, sifatnya konkrit, sering ditemui mereka dan ini baik apalagi sasarannya adalah mereka yang masih dalam kategori pemula untuk belajar bahasa Inggris (Harmer,1991). Menurut perancang bahan ajar yang sekaligus sebagai pengajar mengatakan bahwa topik-topik yang dipilih tidak asing lagi bagi peserta didik dan hal ini juga ditegaskan oleh mereka. Selesai memperlihatkan berbagai foto, peserta didik disajikan tujuh permainan (quiz) dalam rangka mengembangkan keterampilan berbahasa Inggris yaitu dengan menggunakan foto-foto yang sama. Setiap foto dilengkapi empat kata di sebelah kanannya, mereka diharuskan memilih satu kata yang dianggap benar dari keempat kata tersebut. Misalnya foto yang ditampilkan berupa Kantor Pos yang disampingnya ada empat kata yang berkaitan dengan foto tersebut. Di atasnya ada perintah "Choose the most suitable answer related to the Post Office from the four!" Keempat kata yang harus dipilih oleh peserta didik "envelope, stamp, paper, glue."

Bila peserta didik memilih dan menekan tombol di depan pilihan kata yang salah, di tombol itu akan terlihat pancaran sinar tanda $x$ dan bila memilih yang benar akan terlihat tanda $v$ yang secara otomatis diikuti dengan tampilnya kata "congratulation". Bila "congratulation" di tekan akan terlihat tampilan permainan berikutnya dengan instruksi yang sama atau yang berbeda seperti "The following are words related to Beach except....". Permainan seperti ini bukan merupakan hal yang baru dalam belajar berbahasa asing. Namun, karena mereka tergolong pemula dan mungkin pertama kali bagi mereka dalam belajar dengan menggunakan TIK, nampaknya mereka senang dengan permainan tersebut. Di sisi lain, permainan tersebut dapat dijadikan alat pengukur diri atau "self evaluation" dan akan cocok bila model pembelajaran seperti itu akan dimasukkan ke website dimana penggunanya mengadakan 
evaluasi diri secara mandiri. Setelah sesi pertama yang diakhiri dengan penampilan tombol berwarna merah di tengah bawah layar, guru menekan tombol tersebut agar daftar isi tampil kembali di layar.

Setelah daftar isi tampil kembali di layar, kemudian guru menekan judul "Core Activities"kegiatan utama agar dapat memulai sesi kedua. Kegiatan untuk sesi ini cukup lama dan pada intinya responden diberi kesempatan mengembangkan empat keterampilan berbahasa: mendengarkan, berbicara, membaca dan menulis yang diakhiri dengan permainan lagi, namun dalam bentuk yang berbeda. Guna mendukung keterampilan mendengarkan dan berbicara misalnya, bahan dan proses pembelajarannya sebagai berikut. Pertama, disajikan suatu dialog lisan sederhana yang ada hubungannya dengan beberapa foto tentang tempat umum seperti diuraikan di atas, disertai dengan teksnya yang berjalan dalam kecepatan normal. Bila dialog selesai, teks tertulisnya akan diam selama guru tidak menekan anak panah yang mengarah ke sebelah kanan. Ketika diam peserta didik dapat membaca bersuara teks tersebut berulang kali. Tetapi bila ditekan akan ada dialog lisan berikutnya disertai teksnya yang berjalan. Tampilan dialog kedua nampaknya lebih kompleks/panjang, namun seperti dialog sebelumnya setiap selesai satu giliran, teks akan berhenti selama guru yang menyajikan tidak menekan anak panah yang mengarah ke sebelah kanan. Bila guru menekan anak panah ke sebelah kiri akan terbaca kembali teks sebelumnya (dialog pertama.)

Dalam rangka pengembangan keterampilan membaca, sesi ini menyajikan empat teks/cerita dalam bahasa Inggris sederhana dengan judul masing-masing, "Bali Museum", "Art Center", "City Park", "Jagatnatha." Setiap teks dilengkapi dengan foto yang sesuai dan diikuti oleh lima pertanyaan yang jawabannya ada di dalam teks itu sendiri. Keempat, teks tersebut relatif sama bila dilihat dari sisi tingkat kesulitan maupun panjangnya teks. Pada penampilannya teks-teks tersebut disertai suara bacaannya, berjalan dengan kecepatan normal. Salah satu dari keempat teks dimaksud sebagai berikut.

\section{Bali Museum}

In Denpasar there is a museum "Bali Museum". It is on Jalan Mayor Wisnu. It was founded by the Dutch in 1932. We see traditional temple and palace architecture. There is a large building the style of Karangasem Kingdom. We also find style from Singaraja and Tabanan. There is a place for exhibition from Balinese stone age to modern works. Special features are stone sculpture, dance masks and skill models of ceremonial events. There are also big "Barong Landung" figures. It is open everyday. If you want to visit the Bali Museum you have to buy a ticket at the gate. Inside the museum there are tour guides. They are very polite and can speak foreign languages. One of them will guide you around the museum, show you interesting places and explain the history.

\section{Answer the question below!}

1. Where is Bali Museum located?, 2. When was Bali Museum founded?, 3. What can you see in Bali Museum?, 4. Who can guide you in the museum?, 5. What do you call the museum in Denpasar?

Selesai tampilan suatu teks, secara otomatis teks diam selama guru tidak menekan tombol untuk pindah ke teks berikutnya. Setiap selesai satu teks guru mengajukan pertanyaan kepada peserta didik dengan mengatakan "Apakah ada kata yang sulit untuk dipahami dari teks tersebut? Pertanyaan ditanggapi oleh sebagian kecil responden dan bahkan adakalanya pertanyaan dari guru tidak direspon sama sekali oleh mereka. Sebenarnya ketika suatu teks terlihat semuanya dan berhenti, pada kesempatan ini guru sebaiknya menugaskan peserta didik membaca bersuara dan melatih menulis kata-kata yang ada di teks dan bila memungkinkan mereka juga menulis kalimat sederhana dengan menggunakan kata yang ada di setiap teks tersebut. Manfaatnya agar mereka lebih lancar dalam berbicara dan menulis serta lebih percaya diri dalam menguasai bahasa sasaran mereka, namun hal ini tidak dilaksanakannya dengan alasan waktu yang sangat terbatas.

Selesai pengembangan keterampilan membaca kemudian diikuti dengan kegiatan pengembangan keterampilan menulis yang materinya disusun dalam bentuk permainan. Ada 
sepuluh nomor permainan dengan pola yang sama yaitu empat pilihan kalimat sederhana dengan kata-kata yang diacak (tidak mengikuti kaidah bahasa tersebut) kecuali satu yang mengikuti kaidah (benar) seperti berikut.

Which one do you think the correct sentence?

1. stamp - a - buy - will - I.

2. buy - a - I- stamp - will.

3. will - I- buy - a - stamp.

4. I- will - buy - a - stamp.

Guna mengetahui kalimat yang dipilih benar atau salah, guru menugaskan peserta didik untuk memilih satu dari keempat pilihan dan guru menggerakkan kursornya sesuai dengan pilihan peserta didik. Pilihan peserta didik nampak bervariasi, namun guru mengikuti keinginan mereka dengan memilih pilihan satu persatu dan nampaknya guru dengan sengaja mulai memilih pilihan peserta didik dari yang salah terlebih dahulu.

Ketika guru memilih pilihan yang salah pada tombol yang disediakan, maka terlihat pancaran sinar dengan simbol $x$. Kemudian guru memilih pilihan lain yang juga masih dianggap salah oleh guru dan pada akhirnya guru memilih pilihan jawaban yang oleh sebagian peserta didik dianggap benar.

Ketika guru memilih pilihan yang benar, kemudian terlihat pancaran sinar dengan simbol ". Setelah selesai guru tidak membahas tentang tata bahasa yang melandasi pilihan jawaban yang benar. Langkah ini baik agar peserta didik tidak selalu berkonsentrasi kepada "grammatical point" yang akan menimbulkan kehati-hatian mereka dalam menggunakan bahasa Inggris, apalagi mereka masih pada tahap awal dimana untuk mereka bahan yang diajarkan sebaiknya mulai dari kata dan frase terlebih dahulu sebelum tata bahasa Willis J. (1999), apalagi ditegaskan oleh Woods (1995) bahwa tidak ada perbedaan yang sifnifikan dalam kemampuan berkomunikasi lisan antara peserta didik yang belajar tata bahasa dengan yang tidak. Selama melaksanakan permainan tersebut, peserta didik terlihat senang, mereka memiliki semangat yang tinggi, berlomba agar pilihan mereka didahulukan dipilih oleh guru sehingga suasana di kelas menjadi gaduh.
Berakhirnya kesepuluh permainan diikuti dengan sepuluh permainan lainnya, yaitu mencocokkan kata/frasa yang ada di sebelah kiri dengan fungsinya di sebelah kanan. Misalnya frasa yang di sebelah kiri "Post Office" salahsatu kata yang ada kaitannya/relevan dengan fungsinya adalah "send a letter". Menurut guru yang merancang, tampilan permainan ini guna mengecek penguasaan pengetahuan umum melalui bahasa yang menjadi target mereka.

Selesai sesi kedua atau utama, guru kembali ke daftar isi guna menekan yang bertuliskan "Post Activities" sebagai sesi ketiga atau sesi terakhir, terdiri dari beberapa bentuk kegiatan, termasuk tes. Kegiatannya dimulai dengan penyajian sepuluh kosakata yang dianggap sulit untuk diucapkan/dilafalkan. Peserta didik kemudian ditugaskan untuk melihat ke dan mendengarkan ucapan dari tayangan dan mereka dianjurkan mengikutinya. Beberapa contoh kata yang harus diikuti ucapannya oleh mereka antara lain "architecture, ancient, sculpture". Kegiatan pelafalan menjadi penting dalam rangka pengembangan keterampilan berbahasa lisan. Disamping kegiatan pelafalan, diadakan pengukuran kemampuan menyimak dan menulis kalimat sederhana yang didiktekan. Kegiatannya, peserta didik mendengarkan satu kalimat dari lima kalimat yang dibacakan, kemudian mereka menulisnya. Dua contoh dari lima kalimat yang dibacakan seperti berikut: "You can read books in the library, Go straight in this way". Setelah selesai, kelima kalimat tertulis yang benar ditampilkan di layar dan peserta didik ditugaskan untuk memeriksa sendiri hasil tulisan mereka.

Dari hasil pengamatan selama pelaksanaan ujicoba hasil pengembangan kurikulum bahasa Inggris yang dilaksanakan di kelas V SD Tulangampiang, guru terlihat tidak dominan dan hanya memberi motivasi dan bantuan kepada peserta didik. Selama mengajar tujuh puluh menit tersebut guru sesekali mendekati peserta didik dan menyusuh mereka menjawab pertanyaan, mengikuti perintah, mengikuti/mengulangi ucapan dan menanyakan adatidaknya kata-kata yang belum difahami maknanya. Jadi nampak guru cenderung hanya sebagai fasilitator (Breen dan Candlin, 1980), dan beliau menegaskan bahwa bahan yang disusun dan dipraktikkan di kelas 
termasuk materi yang telah disesuaikan dengan kemampuan mereka yang menjadi muridnya sehari-hari.

Topik-topik yang menjadi "payung" bahan ajar yang digunakan nampak tidak asing lagi bagi mereka, begitu pula dengan kosakata sebagai "bahan mentah" dalam penyusunan bahan ajar nampak tidak sulit. Meskipun demikian, dalam pelaksanaannya guru masih menanyakan secara klasikal kepada mereka tentang adatidaknya kosakata yang dianggap sulit/belum difahami maknanya. Nampaknya tidak banyak dari mereka yang memberi tanggapan atas pertanyaan tersebut, dan sebanyak 97,05\% dari mereka mengatakan kosakata yang disajikan tidak terlalu sulit/sedang, sementara yang mengatakan "sulit" sebanyak hanya $2,94 \%$. Juga nampak bahwa kalimat, paragraph dan teks/cerita disajikan dalam bentuk yang sederhana (mudah dan pendek) dan tidak nampak menggunakan banyak kosakata baru dalam setiap teks sehingga beban peserta didik tidak berat (Finocchiaro dan Brumfit, 1983). Dialog dan cerita sebagai bagian dari bahan pembelajaran nampak dikaitkan dengan kehidupan sehari-hari peserta didik. Hal ini terjadi karena sejak awal pemilihan topik yang akan digunakan terlihat sudah mengarah kepada konteks kehidupan mereka sehari-hari dan ini sesuai dengan yang dianjurkan oleh Nunan, D. (1989) dan Cameron, L. (2001).

Hubungannya dengan soal tes yang harus dijawab oleh peserta didik, 82,35\% dari mereka mengatakan soal tes sedang. Ini menunjukkan bahwa tes yang disajikan termasuk kategori menantang bagi sebagian besar responden, dan menurut guru yang merancangnya bahwa soalsoal tersebut juga dapat dijadikan bahan permainan atau "games" yang sifatnya mendidik mereka. Dengan permainan yang merupakan bagian dari kegiatan kebahasaan, ini merupakan alat yang efektif, penyeimbang dan nampaknya telah disesuaikan dengan kemampuan peserta didik (WIKIPEDIA, 2010a). Bila dilihat dari sisi bahan ajar yang disajikan secara keseluruhan melalui berbagai kegiatan, terlihat bahan ajar dan jenis kegiatan dapat dikategorikan mudah, namun menantang, menyenangkan dan memberi motivasi (PP Nomor 19 Tahun 2005).

Peserta didik yang juga menjadi responden nampak sangat antusias dengan bahan yang disajikan. Mereka memperhatikan tayangan di layar secara sungguh-sungguh dengan mendengarkan ungkapan secara lisan yang harus diikutinya. Mereka juga terlihat mengikuti perintah untuk mengucapkan/melafalkan kata-kata yang ada. Ucapan/pelafalan yang dilakukan oleh mereka terdengar relatif baik pada tingkatan yang dapat diterima atau "acceptable level". Kesungguhan mereka dalam memperhatikan tayangan bahan merupakan suatu indikasi positif dan ini didukung oleh sebagian besar responden. Sebanyak $88,23 \%$ dari mereka mengatakan bahan yang ditayangkan disertai dengan permainan berbahasa Inggris "menarik", 11,76\% mengatakan "sangat menarik" karenanya selama pembelajaran berlangsung mereka nampak senang. Ditanya tentang menarik atau tidak fofofoto yang disajikan dalam pembelajaran, 2,94\% responden mengatakan "sangat menarik", $85,29 \%$ mengatakan "menarik". Adanya sebagian besar responden menyatakan positif tentang tayangan bahan ajar yang mereka ikuti, ini menunjukkan bahwa bahan ajar dengan menggunakan TIK dapat memotivasi mereka dan menimbulkan rasa senang dalam belajar bahasa Inggris.

Menurut responden bahan ajar menjadi menarik juga karena cerita yang disajikan diambil dari lingkungan mereka dan berbagai permainan yang tidak sulit untuk difahami dan dilaksanakan. Adanya tampilan tiga aspek (berbagai foto yang berwarna warni, cerita pendek yang diambil dari lingkungan mereka dengan penggunaan kosakata, paragraph yang mudah dan sederhana serta berbagai permainan yang membuat mereka senang) seiring dengan saran yang disampaikan oleh Penny Ur (1996).

Dengan permainan yang menarik, mereka terlihat berpikir secara sungguh-sungguh dalam rangka mengembangkan keterampilan berbahasa, karena itu permainan seperti itu dapat dianggap sebagai pondasi atau landasan yang baik untuk belajar berbahasa (http://www. Learning gamesforkids.com). Karena itu pula, emosi mereka diberdayakan untuk melakukannya secara maksimal(SHVOONG, 2007).

Adanya beragam kegiatan yang bermakna dalam belajar bahasa nampaknya dipengaruhi 
oleh adanya media sebagai sarana belajar (Jurusan Kurikulum dan Teknologi Pendidikan, FIPUPI, 2007). Dengan berbagai permainan pula peserta didik terlihat aktif walaupun hanya kognitifnya (California http://pubs. cde.ca.gov/ tcsii/ap/glossary.aspx) sementara fisiknya tidak aktif/pasif karena mereka hanya diam di kursi masing-masing. Kondisi ini sekaligus menunjukkan bahwa pendapat California http:// tersebut tidak seutuhnya dapat dilaksanakan didalam model pembelajaran berbasis TIK seperti diuraikaj di atas, begitu pula dengan PP Nomor 19, Tahun 2005 Bab IV Tentang Standar Proses, pasal 19 ayat 1 . Situasi pasif secara fisik juga tidak menimbulkan komunikasi berbahasa Inggris diantara peserta didik yang dapat bermanfaat bagi mereka dalam mengembangkan keterampilan berbahasa lisan dan tulisan. Karena itu kondisi di kelas dimana peserta didik tidak mengadakan komunikasi lisan dan tertulis juga tidak sesuai dengan saran yang disampaikan oleh para ahli seperti Richards dan kawan-kawan (1994), (Rivers 1987), Hyde (1993), Holliday (1994), dan Harmer (1991). Walaupun peserta didik tidak melaksanakan komunikasi lisan dan tertulis, namun dari uraian di atas dapat disimpulkan bahwa mereka merasa senang selama kegiatan pembelajaran.

Meskipun pembelajaran menggunakan TIK yaitu Laptop dan Infocus, namun dari hasil telaahan menunjukkan bahwa bahan yang disajikan sesuai dengan tujuan yang tertuang di dalam RPP. Dengan penggunaan TIK, nampak bahwa peserta didik lebih proaktif dalam memahami semua materi yang mereka lihat dan dengar dan ini dimungkinkan lebih dapat meningkatkan hasil belajar mereka (Anonim, Jurusan Kurikulum dan Teknologi Pendidikan, FIPUPI, 2007).

Tetapi pembelajaran dengan TIK seperti yang dipraktikkan di SD tersebut memerlukan alat utama yang mahal, seperti Laptop dan Infokus yang mungkin menjadi hambatan bagi sebagian SD lain untuk memilikinya. Apalagi Infokus memiliki keterbatasan dalam penayangan, dan bila ada komponen yang rusak harus diganti dengan biaya yang cukup mahal. Bagi guru yang menyajikan, dengan Infocus dan Laptop nampak bahwa penggunaan waktu lebih efisien dan efektif, guru tidak dominan dan nampak cenderung sebagai fasilitator (Breen dan Candlin, 1980). Dengan TIK, apalagi akan dimasukkan ke website, bahan ajar akan dapat diketahui oleh orang banyak dalam waktu yang relatif singkat (Wikipedia.2010b) dan dengan TIK pula peserta didik memperoleh kemudahan dalam proses pengembangan keterampilan berbahasa (Wikipedia, 2010c).

\section{Simpulan dan saran Simpulan}

Simpulan hasil penelitian adalah guru bahasa Inggris di SD Tulangampiang, Denpasar Bali mengembangkan kurikulum berdasarkan SK dan KD minimal yang ada di SI 2006. Mereka mengembangkan kurikulum (silabus dan RPP) sesuai dengan Peraturan pemerintah, panduan yang dikeluarkan oleh Badan Standar Nasional Pendidikan (BSNP), serta peraturan yang dituangkan didalam lampiran standar proses. Bahan ajar dikembangkan berdasarkan silabus dan RPP yang dirancang sebelumnya meliputi: topik, gambar/foto, kosakata, pelafalan, kalimat, paragraph, teks, jenis kegiatan. Topik-topik dan gambar/foto yang dipilih disusun sedemikian rupa agar menarik dan sesuai dengan kemampuan peserta didik yang juga merangkap sebagai responden. Kosakata, pelafalan terlihat mudah, begitu pula menurut guru yang menyusun dan responden yang mengikuti kegiatan pembelajaran tersebut. Dari sisi tampilan baik kalimat, paragraph di dalam cerita juga jenis permainan yang disajikan termasuk kategori sederhana/pendek dan mudah termasuk menurut guru dan peserta didik. Selama kegiatan pembelajaran, guru yang mengajar sesekali mendekati peserta didik, memberi motivasi dan bantuan kepada mereka yang mengalami kesulitan. Di sisi lain secara kognitif peserta didik aktif yaitu memperhatikan apa yang dilihat dan di dengar dari bahan pembelajaran, namun secara fisik mereka hanya duduk di kursi mereka masing-masing. Meskipun demikian mereka merasa senang dengan pembelajaran yang menggunakan TIK tersebut.

\section{Saran}

Model pembelajaran berbasis TIK yang rencananya digunakan melalui website, bila dipraktikkan di kelas, sebaiknya guru yang 
menyajikan mengatur kegiatan pembelajaran yang mengarahkan peserta didik melakukan komunikasi lisan diantara mereka. Dengan kegiatan berkomunikasi lisan seperti itu, mereka diharapkan akan lebih percaya diri dalam berbicara bahasa target mereka. Oleh karena itu, siapapun yang nantinya menggunakan bahan ajar tersebut dari website untuk digunakan di kelas secara klasikal, diharapkan ketika pembelajaran berlangsung jangan hanya konsentrasi kepada bahan yang ada, namun lebih kreatif dalam menciptakan atmosfir yang akan lebih melibatkan peserta didik aktif secara fisik untuk berinteraksi. Kondisi tersebut diperlukan agar sejalan dengan kebijakan pemerintah dan pendapat beberapa para ahli tersebut di atas yang diyakini lebih baik dalam mengembangkan keterampilan berbahasa tersebut.

\section{Pustaka Acuan}

Anonim, Jurusan Kurikulum dan Teknologi Pendidikan, FIP-UPI. 2007. Media Pembelajaran, dalam http://kurtek. upi.edu/ media diunduh 23 Januari 2010.

Badan Standar Nasional Pendidikan (BSNP). 2006. Panduan Penyusunan Kurikulum Tingkat Satuan Pendidikan jenjang pendidikan dasar dan menengah, Jakarta.

Breen, M.P. \& C.N. Candlin. 1980. "The Essentials of the Communicative Curriculum in Language Teaching". Applied Linguistics, Vol. 1, Nomor 2, hal. 89-112.

California http://pubs. cde.ca.gov/tcsii/ap/glossary.aspx, diunduh 23 Januari 2010.

Cameron, L. 2001. Teaching Languages to Young Learners. Cambridge Language Teaching Library. Cambridge, Cambridge University Press.

Departemen Pendidikan dan Kebudayaan, 1994, Struktur Program Kurikulum 1994, Balitbang Dikbud, Jakarta.

Finocchiaro, M. \& C. Brumfit.1983. The functional-Notional Approach. From Theory to Practice, Oxford University Press.

Harmer, J. 1991. The Practice of English Language Teaching, New Edition. Longman Group UK Limited. Holliday, A. 1994. Appropriate Methodology and Social Context. Cambridge, Cambridge University Press. http://www. Learning gamesforkids.com/., diunduh 23 Januari 2010.

Hyde, M. 1993. "Pair Work- A Blessing or a Course?: An Analysis of Pair Work from Pedagogical, Cultural, Social and Psychological Perspectives". System, Vol. 21, No. 3, hal. 343-348.

Instruksi Presiden Republik Indonesia Nomor 1 Tahun 2010 Tentang Percepatan Pelaksanaan Prioritas Pembangunan Nasional Tahun 2010, khususnya mengenai Prioritas 2, tentang Program Penguatan metodologi dan kurikulum

Nunan, D.1989. Designing Tasks for the Communicative Classroom. Cambridge, Cambridge University Press.

Penny Ur. 1996. A Course in Language Teaching. Practice and theory. Cambridge Teacher Training and Development. Cambridge, Cambridge University Press.

Peraturan Pemerintah Nomor 19 Tahun 2005 Tentang Standar Nasional Pendidikan, Jakarta.

Peraturan Menteri Pendidikan Nasional Nomor 22 Tahun 2006, tentang SI untuk satuan pendidikan dasar dan menengah,Lampiran, bagian SK dan KD bahasa Inggris kelas V SD semester 2, ,Nomor 36, Jakarta.

Peraturan Menteri Pendidikan Nasional Nomor 24 Tentang Pelaksanaan Standar Isi (SI) dan Standar Kompetensi Lulusan (SKL)

Peraturan Menteri Pendidikan Nasional Nomor 41, Tahun 2007 Tentang Standar Proses, Lampiran bagian II Perencaan Proses Pembelajaran

Richards, J.C. \& T.S. Rodgers. 1994. Approaches and Methods in Language Teaching. Cambridge, Cambridge University Press.

Rivers. W.M. 1987. Interaction is the key to teaching language for communication, In Rivers, W.M. (ed) Interactive language Teaching. Cambridge, Cambridge University Press pp.3 - 16. 
Sekolah Dasar Tulangampiang. 2009. Silabus Bahasa Inggris Kelas V, Semester 2, SD Tulangampiang Denpasar, Bali.

Sekolah Dasar Tulangampiang. 2009. RPP Bahasa Inggris Kelas V, Semester 2, Denpasar, Bali.

Sutardi Ambari, Media Jaringan Penelitan, Nomor 5, Maret, 2005

SHVOONG, 2007. Education Games, http://id.shvoong. com/books/1633499-education-games, 19 Juli 2007 (21 April 2010).

Wikipedia. 2010a. Educational game. Children's educational computer games. Whttp:// en.wikipedia.org/wiki/Educational_game, 22 April 2010 diunduh 28 April 2010).

Wikipedia. 2010b. Information and Communication Technology (ICT). http://en.wikipedia.org/wiki/ Information_and_Communication_Technology diunduh 18 April 2010)

Wikipedia. 2010c. Educational technology. http://en.wikipedia.org/wiki/Educational technology 1 April 2010 diunduh 23 April 2010)

Willis J.1999. A Framework for Task-Based Learning. Longman Handbooks for Language Teachers. Edinburgh, England,Addison Wesley Longman Limited.

Woods.1995. Grammar. London, Penguin Group. 